\title{
Antioxidant Activity and Phenolic Composition in 'Beauregard' Sweetpotato Are Affected by Root Size and Leaf Age
}

\author{
Malkeet S. Padda ${ }^{1}$ and D.H. Picha \\ School of Plant, Soil and Environmental Science, Louisiana State University Agricultural Center, \\ 137 J. C. Miller Hall, Baton Rouge, LA 70803
}

\begin{abstract}
ADDITIONAL INDEX wORDS. Ipomoea batatas, nutraceutical, chlorogenic acid, caffeic acid
Abstract. Phenolic acids are considered important antioxidants that may help to prevent many human chronic diseases. The antioxidant activity and phenolic content of sweetpotato [Ipomoea batatas (L.) Lam.] roots and leaves of different sizes and ages, respectively, were quantified. Small roots $(\approx 4 \mathrm{~g}$ root weight) had a higher antioxidant activity and phenolic content compared with full-sized marketable roots ( $\approx 300 \mathrm{~g}$ root weight). Phenolic content in marketable roots was significantly higher in the cortex tissue than in the internal pith tissue. The highest total phenolic content [chlorogenic acid equivalents $\left(10.3 \mathrm{mg} \cdot \mathrm{g}^{-1}\right.$ dry weight)] and antioxidant activity [Trolox equivalents $\left(9.7 \mathrm{mg} \cdot \mathrm{g}^{-1}\right.$ dry weight)] was found in cortex tissue of small-sized roots. Sweetpotato leaves had a significantly higher phenolic content and antioxidant activity than roots. Young, immature unfolded leaves had the highest total phenolic content $\left(88.5 \mathrm{mg} \cdot \mathrm{g}^{-1}\right.$ dry weight) and antioxidant activity $\left(99.6 \mathrm{mg} \cdot \mathrm{g}^{-1}\right.$ dry weight). Chlorogenic acid was the major phenolic acid in root and leaf tissues with the exception of young immature leaves in which the predominant phenolic acid was 3,5-dicaffeoylquinic acid. The results suggest that small-sized roots, which are typically discarded in the field, and young immature leaves may be concentrated sources of phenolic antioxidants.
\end{abstract}

Numerous epidemiological and biomedical studies indicated the consumption of fruits and vegetables rich in polyphenols may help to protect the human body against many chronic diseases such as diabetes, cancer, and cardiovascular ailments (Scalbert et al., 2005). Phenolics are one class of naturally occurring bioactive compounds present in many fruits and vegetables. The antioxidant properties of phenolic compounds have been implicated in suppressing various health-related disorders. Recently, the chemopreventive properties of extract from baked sweetpotato have been associated with the presence of certain phenolic compounds (Rabah et al., 2004). The phenolic acids such as chlorogenic acid (ChlA), 3,5-dicaffeoylquinic acid (3,5-diCQA), 3,4-dicaffeoylquinic acid (3,4diCQA), and 4,5-dicaffeoylquinic acid (4,5-diCQA) extracted from steamed sweetpotato suppressed melanogenesis in mice (Shimozono et al., 1996).

The sweetpotato root is a major staple food widely consumed in developing countries and ranks as the third most important starchy food crop, after cassava (Manihot esculenta Crantz) and potato (Solanum tuberosum L.), in the world (Food and Agriculture Organization of the United Nations, 2006). Also, sweetpotato leaves are consumed as a leafy vegetable in many parts of the world (Villareal et al., 1982). Both sweetpotato roots and leaves are considered to be rich sources of phenolic compounds, which contribute toward the antioxidant activity of sweetpotato tissues (Huang et al., 2004; Islam et al., 2002, 2003b; Walter et al., 1979). However, these previous studies provided no information regarding the effect of root size and leaf age on phenolic composition and antioxidant properties of sweetpotato leaves and root tissues. The small-sized

Received for publication 24 Apr. 2006. Accepted for publication 8 Feb. 2007. Louisiana Agricultural Experiment Station manuscript \#07-14-0013.

We thank Dr. Don Labonte for providing plant material for this research.

${ }^{1}$ Corresponding author. E-mail: mpadda1@1su.edu. roots, which are usually considered waste, could be a potentially rich source of phenolic antioxidants. Also, the leaves at a particular age may have more antioxidant potential and consuming leaves at that stage may be more beneficial for human health. The objective of this study was to determine the effect of root size and leaf age on phenolic composition and antioxidant activity of sweetpotato.

\section{Materials and Methods}

Reagents. Chlorogenic acid, caffeic acid, Folin-Denis reagent, and 1,1-diphenyl-2-picrylhydazyl (DPPH) reagent were purchased from Sigma-Aldrich (St. Louis). Standards of three isomers (4,5-diCQA, 3,5-diCQA, 3,4-diCQA) of isochlorogenic acid were provided by M. Yoshimoto.

Plant material. 'Beauregard' sweetpotatoes were obtained from plants grown under commercial conditions at the Burden Research Center, Baton Rouge, LA, in the 2005 growing season. Roots were harvested after $\approx 4$ months of planting and grouped into four different stages: I to IV, depending on root weight and size (Table 1). Five healthy roots from each root stage were selected for analysis. For leaf analysis, healthy leaf blades were obtained from sweetpotato vines at three different locations: young unfolded leaves from the top of the vine, fully expanded mature leaves from the middle part of the vine, and oldest but fully green leaves near the lower part of the vine. Petioles separated from the oldest leaves were also analyzed.

Tissue PREParation. The selected roots were washed and dried at ambient temperature before tissue preparation. The outer periderm layer was gently removed and the retained inner portion was separated into two tissue types: 1) cortex (the tissue external to the cambium layer) and 2) pith (the tissue internal to the cortex). Both root and leaf tissues were immediately frozen at $-45^{\circ} \mathrm{C}$ and then freeze-dried for $2 \mathrm{~d}$ in a vacuum freeze-dryer (Freezemobile 12EL-Unitop 600L; Virtis Co., Gardiner, NY). 
Table 1. Weight and diameter of sweetpotato roots at different stages. ${ }^{\mathrm{z}}$

\begin{tabular}{lcc}
\hline Root stage & $\begin{array}{c}\text { Root wt } \\
{[\text { mean } \pm \mathrm{SD}(\mathrm{g})]}\end{array}$ & $\begin{array}{c}\text { Root diam } \\
{[\text { mean } \pm \mathrm{SD}(\mathrm{cm})]}\end{array}$ \\
\hline I & $4 \pm 1.1$ & $1.2 \pm 0.2$ \\
II & $26 \pm 7.3$ & $2.6 \pm 0.2$ \\
III & $70 \pm 11.1$ & $3.8 \pm 0.4$ \\
IV & $263 \pm 46.0$ & $6.1 \pm 0.8$ \\
\hline
\end{tabular}

${ }^{\mathrm{z}}$ Each value is the mean of five replications.

Before further extraction, the lyophilized tissue was powdered with a mortar and pestle.

Tissue EXTraction. The powdered root or leaf tissue $(0.5 \mathrm{~g})$ was placed in a $15-\mathrm{mL}$ centrifuge tube (BD Biosciences, San Jose, CA). Approximately $8 \mathrm{~mL}$ of $80 \%$ methanol in deionized water was added to the centrifuge tube. The tubes were capped and immersed in a water bath at $80{ }^{\circ} \mathrm{C}$ for $10 \mathrm{~min}$. After vigorously shaking the heated samples manually for $30 \mathrm{~s}$, the tubes were cooled and centrifuged at $4500 g_{n}$ for $15 \mathrm{~min}$. The clear supernatant was decanted and brought to a final volume of $10 \mathrm{~mL}$ and analyzed for total phenolic content, individual phenolic acids content, and antioxidant activity.

Total Phenolics. Total phenolic content was determined by modification of the Folin-Denis method (Swain and Hillis, 1959). A sample volume of $0.5 \mathrm{~mL}$ was placed in a $25-\mathrm{mL}$ test tube followed by the addition of $8 \mathrm{~mL}$ of Megapure water (Barnstead International, Dubuque, IA) and $0.5 \mathrm{~mL}$ of FolinDenis reagent, respectively. After $3 \mathrm{~min}, 1 \mathrm{~mL}$ of $1 \mathrm{~N} \mathrm{Na}_{2} \mathrm{CO}_{3}$ was added and the solution was allowed to stand for $2 \mathrm{~h}$ at ambient temperature $\left(\approx 22{ }^{\circ} \mathrm{C}\right)$. Absorbance of the resulting blue complex was measured at $750 \mathrm{~nm}$ using an ultraviolet/ visible spectrophotometer (Lambda 35; Perkin Elmer Instruments, Norwalk, CT). A standard curve of chlorogenic acid with concentration ranging from 50 to $300 \mu \mathrm{g} \cdot \mathrm{mL}^{-1}$ was plotted. The total phenolic content was expressed as milligrams of ChlA equivalents per gram dry weight.

Antioxidant ACTIVITy. The antioxidant activity was measured using a method developed by Brand-Williams et al. (1995) with slight modifications. The decrease in absorbance of DPPH free radicals on their reduction by an antioxidant was measured at $520 \mathrm{~nm}$. In this study, Trolox (6-hydroxy-2,5,7,8tetramethyl-chroman-2-carboxylic acid) was used as the standard antioxidant compound. An aliquot $(300 \mu \mathrm{L})$ of sweetpotato extract was placed in a $1.5-\mathrm{mL}$ amber-colored centrifuge tube. Then $600 \mu \mathrm{L}$ of $0.1 \mathrm{M} 2-(\mathrm{N}$-morpholine) ethanesulfonic acid, $\mathrm{pH} 6.0$, and $300 \mu \mathrm{L}$ of $0.4 \mathrm{~mm}$ of DPPH solution were added to the centrifuge tube. The resultant mixture was shaken and held in the dark for $2 \mathrm{~min}$. The decrease in absorbance of DPPH free radicals at $520 \mathrm{~nm}$ was measured using an ultraviolet/Vis spectrophotometer. The sweetpotato extract was replaced with $80 \%$ methanol in the control sample. A solution of $80 \%$ methanol without DPPH was used as a blank. The antioxidant activity was calculated using a standard curve with known concentrations of Trolox and expressed in terms of milligrams of Trolox equivalents per gram dry weight.

INDIVIDUAL PHENOLIC ACIDS. An aliquot of the supernatant from sweetpotato extract was filtered through a $0.45-\mu \mathrm{m}$ Nylaflo membrane filter (Pall Corp., East Hills, NY) and analyzed for individual phenolic acids. Separation of individual phenolic acids was accomplished using reversed-phase highperformance liquid chromatography (HPLC) with a Gemini C18, 5- $\mu \mathrm{m}, 4.6 \times 250-\mathrm{mm}$ column (Phenomenex, Torrance,
CA). The column oven temperature was set at $30^{\circ} \mathrm{C}$. A sample volume of $20 \mu \mathrm{L}$ was injected onto the column using a Waters 717 autosampler connected to a Waters 600E pump (Waters Corp., Milford, MA). Phenolic acids were eluted using a mobile phase consisting $1 \%(\mathrm{v} / \mathrm{v})$ formic acid in aqueous solution: acetonitrile: 2-propanol (70:22:8), $\mathrm{pH} 2.5$. Isocratic elution was performed with a flow rate of $0.75 \mathrm{~mL} \cdot \mathrm{min}^{-1}$. Peaks were detected at $320 \mathrm{~nm}$ using a Waters 2487 dual-wavelength ultraviolet absorbance detector. Detected peaks were identified and quantified by comparing the retention time and peak area to that of known standards.

StatistiCal AnALYSIS. A completely randomized design was used with five replications. Each root was considered a replication. For leaf analysis, 10 to 15 leaves at each leaf age were randomly selected from 10 to 15 different plants. The selected leaves at each age were combined and considered as a replication. Data were analyzed by SAS procedure MIXED (SAS Institute, Cary, NC). Analysis of variance was performed and significance of differences among means was determined by Tukey's test $(P \leq 0.05)$. A Pearson correlation test $(P \leq$ 0.05 ) was used to determine the relationship between total phenolic content and antioxidant activity.

\section{Results and Discussion}

Total Phenolics. The small-sized roots at stage I had a significantly higher $(P \leq 0.05)$ total phenolic content $(10.3$ $\mathrm{mg} \cdot \mathrm{g}^{-1}$ dry weight in cortex and $9.0 \mathrm{mg} \cdot \mathrm{g}^{-1}$ dry weight in pith) than the larger sized roots at all other stages (Fig. 1). Previously, a decrease in concentration of total phenolic content with development of potato tubers was attributed to a dilution effect resulting from an increase in tuber weight (Reyes et al., 2004). If this assumption is also true for sweetpotato, the total phenolic content in roots at stages II, III, and IV should be significantly different. However, the results indicated that total phenolic content in the same root tissue at stages II, III, and IV were not significantly different. Previous researchers indicated that exogenous application of naphthaleneacetic acid increased the soluble phenolics in soybean [Glycine $\max$ (L.) Merr.] cuttings (Liu et al., 1996). Consequently, we hypothesized that small-sized roots may have a high auxin level facilitating accumulation of more phenolic compounds. As reported previously (Walter and Schadel, 1981), cortex tissue had higher total phenolics than the pith tissue, although no significant differences were observed in small-sized roots at stage I.

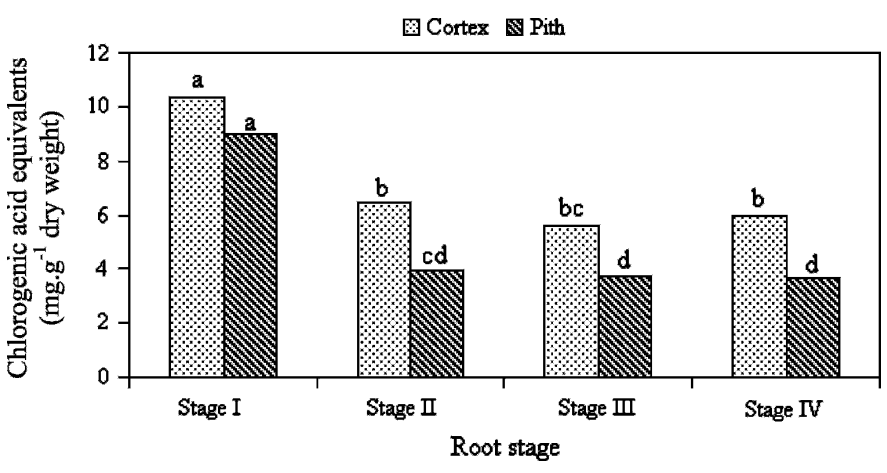

Fig. 1. Total phenolics (milligrams of chlorogenic acid equivalents per gram dry weight) in tissues from sweetpotato roots at different stages. Mean values with different letters are significantly different at $P \leq 0.05$ (Tukey's test). 
In agreement with Islam et al. (2002), our results indicated sweetpotato leaves had a significantly higher total phenolic content than root tissues. In addition, this study revealed total phenolic content varies with the age of sweetpotato leaf tissue (Table 2). The concentration of phenolic compounds in young leaves was significantly higher than in mature and old leaves. Results also indicated the leaf blade had a higher total phenolic content than the petiole. Total phenolic content in the young leaf blade $\left(88.5 \mathrm{mg} \cdot \mathrm{g}^{-1}\right.$ dry weight $)$ was $\approx 4$-fold higher than in the old leaf blade $\left(21.8 \mathrm{mg} \cdot \mathrm{g}^{-1}\right.$ dry weight $)$, which in turn was $\approx 3$-fold higher than in the petiole $\left(7.9 \mathrm{mg} \cdot \mathrm{g}^{-1}\right.$ dry weight).

Table 2. Total phenolics and antioxidant activity in sweetpotato leaf tissue at different ages.

\begin{tabular}{lcc}
\hline Leaf age & $\begin{array}{c}\text { Total phenolics } \\
{\left[\mathrm{CAE}\left(\mathrm{mg} \cdot \mathrm{g}^{-1} \mathrm{dry} \mathrm{wt}\right)\right]^{\mathrm{z}}}\end{array}$ & $\begin{array}{c}\text { Antioxidant activity } \\
{\left[\mathrm{TE}\left(\mathrm{mg} \cdot \mathrm{g}^{-1} \mathrm{dry} \mathrm{wt}\right)\right]^{\mathrm{y}}}\end{array}$ \\
\hline Young & $87.29 \mathrm{a}^{\mathrm{x}}$ & $99.61 \mathrm{a}$ \\
Mature & $27.77 \mathrm{~b}$ & $31.11 \mathrm{~b}$ \\
Old & $21.56 \mathrm{~b}$ & $21.04 \mathrm{~b}$ \\
Petiole & $7.62 \mathrm{c}$ & $9.65 \mathrm{c}$ \\
\hline
\end{tabular}

${ }^{\mathrm{z} C h l o r o g e n i c}$ acid equivalents (CAE).

yTrolox equivalents (TE).

${ }^{x}$ Mean values with a different letter in a column are significantly different at $P \leq 0.05$ (Tukey's test).

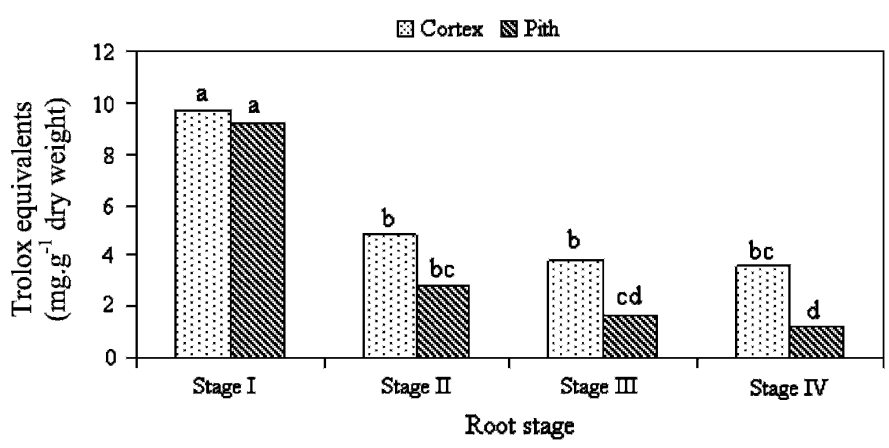

Fig. 2. Antioxidant activity (milligrams of Trolox equivalents per gram dry weight) in tissues from sweetpotato roots at different stages. Mean values with different letters are significantly different at $P \leq 0.05$ (Tukey's test).

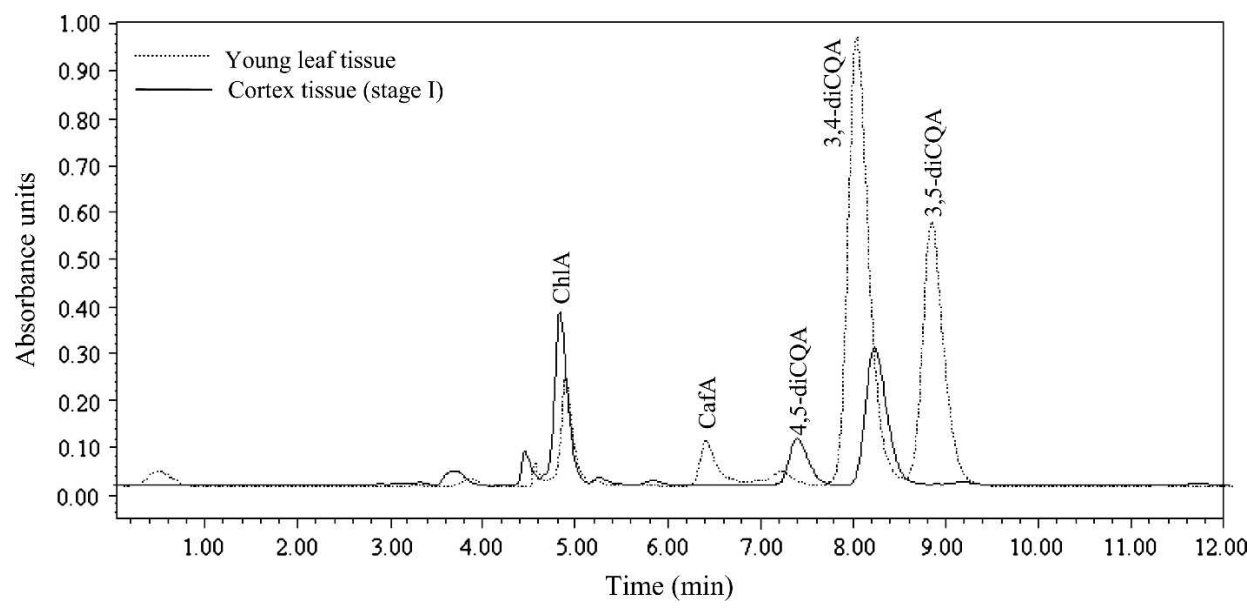

Fig. 3. Comparison of high-performance liquid chromatograms for individual phenolic acids isolated from young leaf tissue and root cortex tissue at stage I; ChlA = chlorogenic acid; CafA = caffeic acid; diCQA = dicaffeoylquinic acid.
Previous reports indicated the young leaves from tea [Camellia sinensis (L.) O. Kuntze] and strawberry (Fragaria ×ananassa Duch.) had higher total phenolic content than old leaves (Lin et al., 1996; Wang and Lin, 2000). The higher phenolic content in young leaf tissue may be the result of higher auxin levels. Studies on other crops indicated the phenolic compounds regulate auxin transport and accumulate in tissues with high auxin production (Faivre-Rampant et al., 2000). This information implies a potential for using exogenous sprays of auxin to increase health-beneficial phytochemicals in sweetpotato leaves.

AnTIOXIDANT ACTIVITY. The changes in antioxidant activity of root and leaf tissues of sweetpotatoes paralleled that of total phenolic content. Roots at stage I had significantly higher antioxidant activity $\left(9.7 \mathrm{mg} \cdot \mathrm{g}^{-1}\right.$ dry weight in cortex and $9.2 \mathrm{mg} \cdot \mathrm{g}^{-1}$ dry weight in pith) than roots at the other three stages (Fig. 2). Similar to the total phenolic contents, the antioxidant activities in sweetpotato roots at stages II, III, and IV were not significantly different. Cortex tissue from roots at stages III and IV had higher antioxidant activity than the pith tissue; however, no significant differences were found at stages I and II. Wang and Lin (2000) reported the small green stage in a developing strawberry fruit had the highest antioxidant activity. The highest antioxidant activity of roots at stage $\mathrm{I}$ is associated with the highest total phenolic content.

The antioxidant activity of sweetpotato leaves was significantly higher than in root tissues. The highest antioxidant activity (99.6 $\mathrm{mg} \cdot \mathrm{g}^{-1}$ dry weight) found in young leaves was almost 10 times higher than the antioxidant activity in cortex tissue at stage I (9.7 $\mathrm{mg} \cdot \mathrm{g}^{-1}$ dry weight), which had the highest antioxidant activity among root tissues at different stages. The information generated by this study indicated the antioxidant activity of sweetpotato leaves was also significantly affected by leaf age. Antioxidant activity in immature young leaves (99.6 $\mathrm{mg} \cdot \mathrm{g}^{-1}$ dry weight) was significantly higher than in mature (31.1 $\mathrm{mg} \cdot \mathrm{g}^{-1}$ dry weight) and old $\left(21.0 \mathrm{mg} \cdot \mathrm{g}^{-1}\right.$ dry weight) leaves (Table 2). However, the antioxidant activity in old and mature leaves was not significantly different. Concomitant with the lowest total phenolic content, the petiole had the lowest antioxidant activity $\left(9.6 \mathrm{mg} \cdot \mathrm{g}^{-1}\right.$ dry weight). Wang and Lin (2000) also reported the young leaves from berry crops (Rubus L. spp.) had higher antioxidant activity than older leaves. A recent review has indicated that as a result of high antioxidant activity and lower oxalic acid content compared with many leafy vegetables, consumption of sweetpotato leaves may be helpful in maintaining good human health and avoiding many chronic diseases (Islam, 2006).

The correlation coefficients $\left(\mathrm{r}^{2}\right)$ between antioxidant activity and total phenolic content of root and leaf tissue at different ages were 0.979 and 0.998 , respectively $(P \leq$ $0.05)$. Strong correlation coefficients indicate that antioxidant activity of sweetpotato root and leaf tissue increases with increased total phenolic content. Previously, Islam et al. (2003a) reported a positive correlation between antioxidant activity and total phenolic content in sweetpotato leaves. 
Table 3. Phenolic acid content in sweetpotato root tissues at different root stages.

\begin{tabular}{|c|c|c|c|c|c|c|}
\hline \multirow[b]{2}{*}{ Root stage } & \multirow[b]{2}{*}{ Tissue type } & \multicolumn{5}{|c|}{ Phenolic acid content $(\mathrm{mg} / 100 \mathrm{~g} \text { dry } \mathrm{wt})^{\mathrm{z}}$} \\
\hline & & ChlA & CafA & 4,5-diCQA & 3,5-diCQA & 3,4-diCQA \\
\hline \multirow[t]{2}{*}{ Stage I } & Cortex & $164.2 \mathrm{a}^{\mathrm{y}}$ & $2.7 \mathrm{a}$ & $72.1 \mathrm{a}$ & $157.6 \mathrm{a}$ & $10.4 \mathrm{ab}$ \\
\hline & Pith & $141.9 \mathrm{ab}$ & $2.3 \mathrm{a}$ & $69.3 \mathrm{a}$ & $136.0 \mathrm{a}$ & $27.7 \mathrm{a}$ \\
\hline & Pith & $54.6 \mathrm{~cd}$ & $0.4 \mathrm{~b}$ & $14.6 \mathrm{~b}$ & $28.6 \mathrm{bcd}$ & $4.9 \mathrm{~b}$ \\
\hline \multirow[t]{2}{*}{ Stage III } & Cortex & $87.8 \mathrm{c}$ & $0.6 \mathrm{~b}$ & $17.3 \mathrm{~b}$ & $59.7 \mathrm{bc}$ & $6.8 \mathrm{~b}$ \\
\hline & Pith & $38.4 \mathrm{~d}$ & $0.4 \mathrm{~b}$ & $7.6 \mathrm{~b}$ & $20.4 \mathrm{~cd}$ & $3.4 \mathrm{~b}$ \\
\hline & Pith & $34.4 \mathrm{~d}$ & $0.3 \mathrm{~b}$ & $5.8 \mathrm{~b}$ & $14.3 \mathrm{~d}$ & $2.3 \mathrm{~b}$ \\
\hline
\end{tabular}

${ }^{\mathrm{z}} \mathrm{ChlA}=$ chlorogenic acid; CafA $=$ caffeic acid; diCQA $=$ dicaffeoylquinic acid.

${ }^{y}$ Mean values with the same letters in a column are not significantly different at $P \leq 0.05$ (Tukey's test).

INDIVIDUAL PHENOLIC ACIDS. Typical HPLC chromatographs from sweetpotato roots (stage I) and old leaves are shown in Figure 3. Five different individual phenolic acids (ChlA, CafA, 4,5-diCQA, 3,5-diCQA, 3,4-diCQA) were identified in both sweetpotato root and leaf tissues. As indicated in previous reports, the unknown peaks were assumed to be isomers of chlorogenic acid and 3,4,5-tricaffeoylquinic acid but need further confirmation (Islam et al., 2002; Walter et al., 1979). Results for individual phenolic acids content in sweetpotato roots and leaves at different ages are summarized in Tables 3 and 4. Chlorogenic acid was the most abundant phenolic acid in root tissue followed by 3,5-diCQA. The trend of change in individual phenolic acids content paralleled the total phenolic content. Previously, Islam et al. (2003b) reported a positive correlation between caffeoylquinic acid derivatives and total phenolic content of sweetpotato leaves. In addition, it has been observed that roots at stage I had higher amounts of individual phenolic acids, which decreased with increasing root size. The amounts of all identified individual phenolic acids, except 4,5diCQA and 3,4-diCQA, were significantly higher in roots at stage I compared with roots at stages III and IV. Both cortex and pith tissue in roots at stage I had significantly higher amounts of caffeic acid than all other stages. The decline in chlorogenic acid content during growth and development of tomato (Lycopersicon esculentum Mill.) fruit was associated with the corresponding decline in indole-3-acetic acid level (Buta and Spaulding, 1997). However, for this hypothesis to be true for sweetpotatoes, further research is needed to study the indole-3acetic acid level of different sized roots.

Individual phenolic acid content in sweetpotato leaves was significantly higher than in root tissue, which was consistent with a previous report (Islam et al., 2002). Additionally, our results also indicated the leaf phenolic acid profile varied according to the leaf age. The amounts of all individual

Table 4. Phenolic acid content in sweetpotato leaf tissue.

\begin{tabular}{lrrrrr}
\hline & \multicolumn{5}{c}{ Phenolic acid content $(\mathrm{mg} / 100 \mathrm{~g} \text { dry wt })^{\mathrm{z}}$} \\
\cline { 2 - 6 } Leaf age & ChlA & \multicolumn{1}{c}{ CafA } & 4,5 -diCQA & 3,5-diCQA & $3,4-$ diCQA \\
\hline Young & $632.0 \mathrm{a}^{\mathrm{y}}$ & $120.2 \mathrm{a}$ & $140.9 \mathrm{bc}$ & $2998.7 \mathrm{a}$ & $2890.8 \mathrm{a}$ \\
Mature & $444.9 \mathrm{~b}$ & $16.3 \mathrm{~b}$ & $319.3 \mathrm{a}$ & $354.8 \mathrm{~b}$ & $342.3 \mathrm{~b}$ \\
Old & $300.1 \mathrm{c}$ & $8.4 \mathrm{~b}$ & $209.3 \mathrm{~b}$ & $112.6 \mathrm{c}$ & $139.6 \mathrm{c}$ \\
Petiole & $114.8 \mathrm{~d}$ & $2.7 \mathrm{~b}$ & $103.6 \mathrm{c}$ & $114.0 \mathrm{c}$ & $54.0 \mathrm{c}$
\end{tabular}

$\overline{{ }^{\mathrm{z}} \mathrm{ChlA}}=$ chlorogenic acid; $\mathrm{CafA}=$ caffeic acid; diCQA $=$ dicaffeoylquinic acid.

${ }^{y}$ Mean values with the same letters in a column are not significantly different at $P \leq 0.05$ (Tukey's test). phenolic acids, except 4,5-diCQA, in young sweetpotato leaves were significantly higher than in mature and old leaves. Petiole tissue had lower amounts of ChlA than leaf blade tissue. The most abundant phenolic acid in young leaves was 3,5-diCQA, whereas ChlA was the major phenolic acid in mature and old leaves. It has been indicated that phenolic acids in sweetpotato leaves may have anticancer, antidiabetes, antimutagenic, and antibacterial activities to protect the human body from certain chronic diseases (Islam, 2006). Furthermore, considering their high phenolic acids content and antioxidant properties, consumption of young sweetpotato leaves may be more beneficial than mature and old leaves.

\section{Conclusions}

This study may have useful implications for the functional food industry. Results indicated that small-sized discarded root and leaf tissues may be potentially used as good sources of antioxidant phenolic compounds. Also, further research on the medicinal value of phenolic acids might encourage the pharmaceutical industry to use these tissues as a concentrated source of these compounds. Consumption of functional foods originating from immature sweetpotato root and leaf tissues high in phenolic content may have significant positive health benefits. This suggests a possible use for small roots that are typically discarded in the field. Future research to elucidate the mechanisms involved in higher phenolic synthesis in immature tissues would be useful to further enhance the nutraceutical value of sweetpotatoes.

\section{Literature Cited}

Brand-Williams, W., M.E. Cuvelier, and C. Berset. 1995. Use of free radical method to evaluate antioxidant activity. LebensmittelWissenschaft Technologie 28:25-30.

Buta, J.G. and D.W. Spaulding. 1997. Endogenous levels of phenolics in tomato fruit during growth and maturation. J. Plant Growth Regulat. 16:43-46.

Faivre-Rampant, O., C. Kevers, and T. Gasper. 2000. IAA-oxidase activity and auxin protectors in nonrooting, rac, mutant shoots of tobacco in vitro. Plant Sci. 153:73-80.

Food and Agriculture Organization of the United Nations. 2006. Statistical database. 15 Aug. 2006. <http://faostat.fao.org/site/370/ default.aspx>.

Huang, D.J., C.D. Lin, H.J. Chen, and Y.H. Lin. 2004. Antioxidant and antiproliferative activities of sweet potato [Ipomoea batatas (L.) Lam 'Tainong 57'] constituents. Bot. Bul. Academia Sinica 45:179-186 
Islam, S. 2006. Sweetpotato (Ipomoea batatas L.) leaf: Its potential effect on human health and nutrition. J. Food Sci. 71:R13-R21.

Islam, M.S., M. Yoshimoto, K. Ishiguro, S. Okuno, and O. Yamakawa. 2003a. Effect of artificial shading and temperature on radical scavenging activity and polyphenolic composition in sweetpotato (Ipomoea batatas L.) leaves. J. Amer. Soc. Hort. Sci. 128:182187.

Islam, M.S., M. Yoshimoto, and O. Yamakawa. 2003b. Distribution and physiological functions of caffeoylquinic acid derivatives in leaves of sweetpotato genotypes. J. Food Sci. 68:111-116.

Islam, M.S., M. Yoshimoto, S. Yahara, S. Okuno, K. Ishiguro, and O. Yamakawa. 2002. Identification and characterization of foliar polyphenolic composition in sweetpotato (Ipomoea batatas L.) genotypes. J. Agr. Food Chem. 50:3718-3722.

Lin, Y.L., I.M. Juan, Y.L. Chen, Y.C. Liang, and J.K. Lin. 1996. Composition of polyphenols in fresh tea leaves and associations of their oxygen-radical-absorbing capacity with antiproliferative actions in fibroblast cells. J. Agr. Food Chem. 44:1387-1394.

Liu, Z.H., I.C. Hsiao, and Y.W. Pan. 1996. Effect of naphthaleneacetic acid on endogenous indole-3-acetic acid, peroxidase and auxin oxidase in hypocotyl cuttings of soybean during root formation. Bot. Bul. Academia Sinica 37:247-253.

Rabah, I.O., D.X. Hou, S.I. Komine, and M. Fujii. 2004. Potential chemopreventive properties of extract from baked sweet potato (Ipomoea batatas Lam. cv. Koganesengan). J. Agr. Food Chem. 52:7152-7157.
Reyes, L.F., J.C. Miller, and L. Cisneros-Zevallos. 2004. Environmental conditions influence the content and yield of anthocyanins and total phenolics in purple- and red-flesh potatoes during tuber development. Amer. J. Potato Res. 81:187-193.

Scalbert, A., C. Manach, C. Morand, C. Remesy, and L. Jimenez. 2005. Dietary polyphenols and the prevention of diseases. Crit. Rev. Food Sci. Nutr. 45:287-306.

Shimozono, H., M. Kobori, H. Shinmoto, and T. Tsushida. 1996. Suppression of the melanogenesis of mouse melanoma B16 cells by sweet potato extract. J. Jpn. Soc. Food Sci. Technol. 43:313-317.

Swain, T. and W.E. Hillis. 1959. The phenolic constituents of Prunus domestica. I. The quantitative analysis of phenolic constituents. J. Sci. Food Agr. 10:63-68.

Villareal, R.L., S.C. Tsou, H.F. Lo, and S.C. Chiu. 1982. Sweetpotato tips as vegetables, p. 313-320. In: R.L. Villareal and T.D. Griggs (eds.). Sweetpotato Proc. 1st Intl. Symp. Asian Veg. Res. and Dev. Ctr., Shanhua, Taiwan.

Walter, W.M., A.E. Purcell, and G.K. McCollum. 1979. Use of highpressure liquid chromatography for analysis of sweet potato phenolics. J. Agr. Food Chem. 27:938-941.

Walter, W.M. and W.E. Schadel. 1981. Distribution of phenols in 'Jewel' sweet potato [Ipomoea batatas (L.) Lam.] roots. J. Agr. Food Chem. 29:904-906.

Wang, S.Y. and H.S. Lin. 2000. Antioxidant activity in fruits and leaves of blackberry, raspberry, and strawberry varies with cultivar and developmental stage. J. Agr. Food Chem. 48:140-146. 